\title{
A prophylactic vaccine for breast cancer? Why not?
}

\author{
Vincent KTuohy* \\ See related research by Watson and Gusterson, http://breast-cancer-research.com/content/12/4/310
}

In a recent issue of Breast Cancer Research, Watson and Gusterson wrote a viewpoint article [1] about our strategy for developing a prophylactic breast cancer vaccine [2]. The authors base much of their view on several misconceptions and misrepresentations that we wish to clarify.

We did not immunize mice with an antibody as the authors claim in their abstract. We immunized mice with a single injection of whole recombinant mouse $\alpha$-lactalbumin protein, and this single immunization provided highly significant protection and therapy against the growth of tumors in several widely used mouse models for breast cancer.

The authors indicate that our 'approach was based on the hypothesis that removal of an organ will provide protection against cancer developing in that organ' [1]. The notion that excised organs have decreased risk for developing tumors is obviously simplistic and misrepresents our actual hypothesis stated in the first sentence of our article: 'a full-strength autoimmune attack sufficient to induce organ-specific failure may provide protection and therapy against tumors derived from the targeted organ' [2].

The viewpoint questions the efficacy of our strategy by claiming that 'milk proteins are expressed in the gland with every oestrus cycle' [1] but fails to indicate that $\alpha$ lactalbumin is not one of these milk proteins, because its expression in mice occurs only during late stages of gestation and reaches maximal expression only upon lactation [3].

The authors cite two studies supporting their contention that $\alpha$-lactalbumin is not expressed in human breast tumors but fail to cite 11 other studies showing that $\alpha$ lactalbumin is expressed in human breast tumors [4-14]. This focus on target expression in mature tumors is moot since prophylactic vaccination requires effective targeting of proteins expressed in the emerging developing tumor

*Correspondence: tuohyv@ccf.org

Cleveland Clinic, Lerner Research Institute, Department of Immunology, NB30, 9500 Euclid Avenue, Cleveland, OH, 44195, USA perhaps as early as the initial dysplastic stages and not in the fully evolved primary and metastatic tumors.

In regard to the significant inhibition of $4 \mathrm{~T} 1$ breast tumor growth that we observed in $\alpha$-lactalbuminvaccinated $B A L B / c$ mice, the authors state: 'If the experiments had been continued for longer than 32 days, it seems very likely that there would be no real difference between the immunised mice and mock-immunised mice in terms of tumour burden' [1]. We disagree with the authors' speculation about what would have occurred since inhibition in growth of primary 4T1 tumors is more often associated with decreased metastasis and overall increased survival [15].

Perhaps the biggest misconception was the authors' belief that the target population for our vaccine will be teenage girls. We have never proposed this. The design of our vaccine was based on two complementary events that take place in women as they age, namely an increasing risk for developing breast cancer and a corresponding decreasing need for using the aging breast and its retired breast-specific proteins for lactation. Thus, our target population has always been women who are more than 40 years old and has never been teenagers as assumed by the authors. This is clearly stated in the last sentence of our abstract [2].

Finally, we agree with the authors that women differ considerably from mice and that there is legitimate concern that $\alpha$-lactalbumin vaccination may target lactational foci in breasts of non-lactating women. However, the authors failed to indicate that, in the study they cited [16], there was no quantification of the frequency of such foci and that the appearance of these foci in the breasts of non-lactating women was significantly associated with the use of contraceptive hormones available in the late 1970s. We believe that the concern regarding inflammatory consequences in vaccinating women in their $40 \mathrm{~s}$ is real but should be resolved in phase I safety trials and not in a selective interpretation of old, controversial, and sometimes conflicting literature focused on protein expression in mature tumors rather than in the targeted emerging tumor and on non-quantitative studies involving women taking contraceptive sex hormones. 
We remain delighted that our prototypic embryonic vaccine and the implications of our overall strategy for developing a much-needed safe and effective prophylaxis against breast cancer by extending vaccine target selection to retired self-proteins have resonated globally and stirred the hopes of so many breast cancer patients around the world.

\section{Competing interests}

The author declares that he has several pending patent applications for using lactation proteins in cancer vaccination.

Published: 8 December 2010

\section{References}

1. Watson CJ, Gusterson BA: A prophylactic vaccine for breast cancer? Breast Cancer Res 2010, 12:310-311.

2. Jaini R, Kesaraju P, Johnson JM, Altuntas CZ, Jane-Wit D, Tuohy VK An autoimmune-mediated strategy for prophylactic breast cancer vaccination. Nat Med 2010, 16:799-803.

3. Robinson GW, McKnight RA, Smith GH, Hennighausen L: Mammary epithelial cells undergo secretory differentiation in cycling virgins but require pregnancy for the establishment of terminal differentiation. Development 1995, 121:2079-2090.

4. Kleinberg DL, Todd J: a-Lactalbumin in human and subhuman primate normal mammary tissue and in human breast cancer as a marker for prolactin activity. Cancer Res 1978, 38:4318-4322

5. Walker RA: The demonstration of alpha lactalbumin in human breast carcinomas. J Pathol 1979, 129:37-42.

6. Martin RH, Glass MR, Chapman C, Wilson GD, Woods KL: Suppression by bromocriptine of the serum lactalbumin peak associated with human lactogenesis. Clin Endocrinol (Oxf) 1981, 14:363-366.

7. Clayton F, Sibley RK, Ordonez NG, Hanssen G: Argyrophilic breast carcinomas: evidence of lactational differentiation. Am J Surg Pathol 1982, 6:323-333.
8. Lee AK, DeLellis RA, Rosen PP, Herbert-Stanton T, Tallberg K, Garcia C, Wolfe $\mathrm{HJ}$ : Alpha-lactalbumin as an immunohistochemical marker for metastatic breast carcinomas. Am J Surg Pathol 1984, 8:93-100.

9. Lee AK, Rosen PP, DeLellis RA, Saigo PE, Gangi MD, Groshen S, Bagin R, Wolfe $\mathrm{HJ}$ : Tumor marker expression in breast carcinomas and relationship to prognosis. An immunohistochemical study. Am J Clin Pathol 1985, 84:687-696.

10. Cohen C, Sharkey FE, Shulman G, Uthman EO, Budgeon LR: Tumor associated antigens in breast carcinomas. Prognostic significance. Cancer 1987, 60:1294-1298.

11. Wrba F, Reiner A, Markis-Ritzinger E, Holzner JH, Reiner G, Spona J: Prognostic significance of immunohistochemical parameters in breast carcinomas. Pathol Res Pract 1988, 183:277-283.

12. Li X, Zhang J, Gao H, Vieth E, Bae KH, Zhang YP, Lee SJ, Raikwar S, Gardner TA, Hutchins GD, VanderPutten D, Kao C, Jeng MH: Transcriptional targeting modalities in breast cancer gene therapy using adenovirus vectors controlled by alpha-lactalbumin promoter. Mol Cancer Ther 2005, 4:1850-1859.

13. Anderson LM, Swaminathan S, Zackon I, Tajuddin AK, Thimmapaya B, Weitzman SA: Adenovirus-mediated tissue-targeted expression of the HSVtk gene for the treatment of breast cancer. Gene Ther 1999, 6:854-864.

14. Anderson LM, Krotz S, Weitzman SA, Thimmapaya B: Breast cancer-specific expression of the Candida albicans cytosine deaminase gene using a transcriptional targeting approach. Cancer Gene Ther 2000, 7:845-852.

15. Thomas DL, Fraser NW: HSV-1 Therapy of primary tumors reduces the number of metastases in an immune-competent model of metastatic breast cancer. Mol Ther 2003, 8:543-551.

16. Bailey AJ, Sloane JP, Trickey BS, Ormerod MG: An immunocytochemical study of a-lactalbumin in human breast tissue. J Pathol 1982, 137:13-23.

doi:10.1186/bcr 2775

Cite this article as: Tuohy VK: A prophylactic vaccine for breast cancer? Why not? Breast Cancer Research 2010, 12:405. 